\title{
The Effect of Corruption on Carbon Dioxide Emissions in the Mena Region
}

\author{
By Hoda Hassaballa*
}

\begin{abstract}
Corruption has always been accused of having adverse effects on growth. This is because it decreases productivity, leads to accumulation of additional costs and discourages investment. Recently, high concerns are raised about the impact of corruption on the environment. Corruption plays a substantial role in increasing pollution emissions level. In spite of this, empirical investigation of such an issue is still incomplete. For that, this research work represents a step forward in understanding the relationship between corruption and the environment in general and in filling the gap present in the literature in analyzing this relationship in the Middle East and North Africa (MENA) region in particular. Accordingly, this paper studies the corruption-environment relationship empirically through examining the effect of corruption on per-capita carbon dioxide emissions. A Fixed Effect Panel Data model is used to investigate the effects of corruption, percapita income, trade openness and manufacturing on per-capita carbon dioxide emissions level in the MENA region over the period 1996-2013. The results indicate that corruption, per-capita income, trade openness and manufacturing value added are significant determinants of Carbon Dioxide Emissions. Policy implications to improve sustainability and governance are given. These include strong enforcement of law, spreading public awareness and increasing transparency.
\end{abstract}

Keywords: Corruption, environment, MENA region, carbon dioxide emissions and panel data model.

\section{Introduction}

There is a general agreement in the mainstream economics on the negative effects of corruption on the economy. It is widely believed that corruption, especially in developing countries, is the source of all evil. For instance, Olken and Pande (2012) hold corruption responsible for the increase in marginal tax imposed on producers, the slowdown of the economy, and the increase in the social costs of public funds resulting in the inability to take rational economic decisions or to correct for externalities. This is in addition to the commonly listed effects of corruption on growth through its negative effects on productivity, accumulation of additional costs and discouragement of investment. For that, there is more recent attention given by worldwide organization such as the World Bank (WB), the United Nations (UN) and the Organization for Economic Co-operation and Development (OECD) to fight corruption. For example, the WB established a whole database responsible for measuring worldwide governance through indicators of voice and accountability, political stability and absence of violence, government effectiveness, regulatory quality, rule of law and control of corruption. ${ }^{1}$ In addition, the UN in its convention against corruption in 2005 wrote:

Corruption is an insidious plague that has a wide range of corrosive effect on societies. It undermines democracy and the rule of law, leads to violations of human rights, distorts markets, erodes the quality of life and

\footnotetext{
${ }^{1}$ For more information visit http://info.worldbank.org/governance/wgi/index.aspx\#home
} 
allows organized crime, terrorism and other threats to human security to

flourish.

Efforts in the OECD countries were more progressive as 38 countries approved the OECD Antibribery convention since in 1998 (Olken and Pande, 2012).

Nevertheless, neither corruption is eliminated nor its effects have disappeared. This put more emphasis on the importance of studying corruption and raises doubts about the enforcement of and compliance with such international conventions and agreements. Not only this, but also corruption became more violent and spread among various sectors in developing economies in general and the MENA region in particular. Currently, high concerns are raised about the impact of corruption on environment. Corruption plays a substantial role in increasing pollution emissions level. In spite of this, empirical investigation of such an issue is not comprehensive. Accordingly, the research objective of the current research work is to examine the effect of corruption on pollution emissions level in the MENA region. For that, this research paper constitutes a step forward in studying the effects of corruption on the environment. This is to shed the light on such an important issue that has its implications on many generations to come.

The rest of the paper is organized as follows: section 2 gives a quick overview of MENA region's economy, corruption and pollution emissions levels. Section 3 provides the needed literature and empirical reviews. Section 4 presents the empirical model and reveals the results and finally section 5 concludes and suggests corresponding policy implications.

\section{Economy, Corruption and the Environment in the Mena Region}

The MENA region consists of 21 countries in the Middle East and North Africa. ${ }^{2}$ To describe the economies of these countries, one cannot escape the effects of the political predicament these countries are going through. Violence and aggression wasted the lives of many people in Libya, Syria, Iraq and Gaza and resulted into a severe deterioration of such countries' economies. ${ }^{3}$ Egypt, Yemen and Tunisia are still suffering from low rates of growth, unemployment, inflation and above all political and economic instability as a result of the Arab Spring. The economic conditions in the remaining countries are much better especially for rich oil countries. However, they all share the violent threats of Islamic State of Iraq and Syria (ISIS) with their relevant economic consequences.

A quick snapshot of the MENA region economies is provided through describing their rates of inflation, rates of unemployment and GDP per capita. Figure (1) shows that rate of inflation in 2013 in some selected countries of the MENA region. It can be deduced that Iran had the highest rate of inflation with 39.3\% in contrast to The United Arab of Emirates that had the $1.1 \%$ rise in prices. Arab Spring effects on prices are obvious in the cases of Egypt, Tunisia and Yemen as they are ranked after Iran. Unemployment rate is the highest in West Bank and Gaza as illustrated in figure (2). It is not a surprise that Qatar has the lowest rate of unemployment in the MENA region with $0.5 \%$ of the labor force are unemployed. Finally, comparing these to GDP per capita, it can be deduced from figure (3) that Qatar enjoys the highest per capita income in the region as opposed to Yemen, Djibouti and West Bank and Gaza

2 These countries are Algeria, Bahrain, Djibouti, Egypt, Iran, Iraq, Israel, Jordan, Kuwait, Lebanon, Libya, Malta, Morocco, Oman, Qatar, Saudi Arabia, Syria, Tunisia, United Arab of Emirates, West Bank \& Gaza and Yemen.

3 http://www.worldbank.org/en/region/mena/overview\#1 


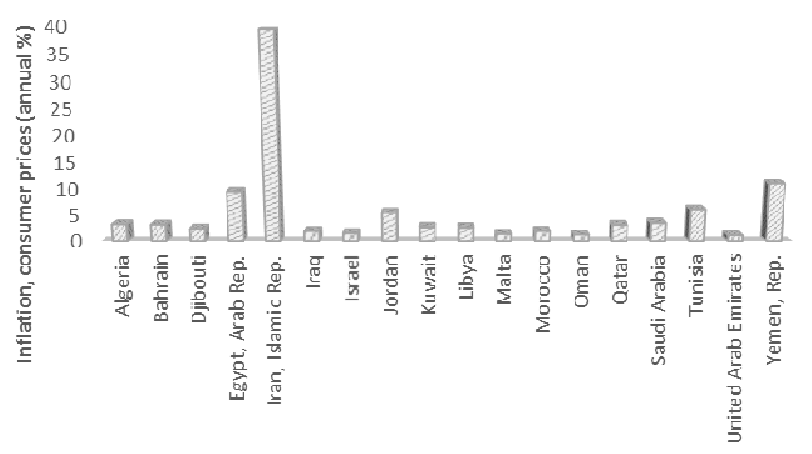

MENA Countries

Figure (1): Rates of Inflation in MENA Region in 2013

Source: The World Development Indicators Database

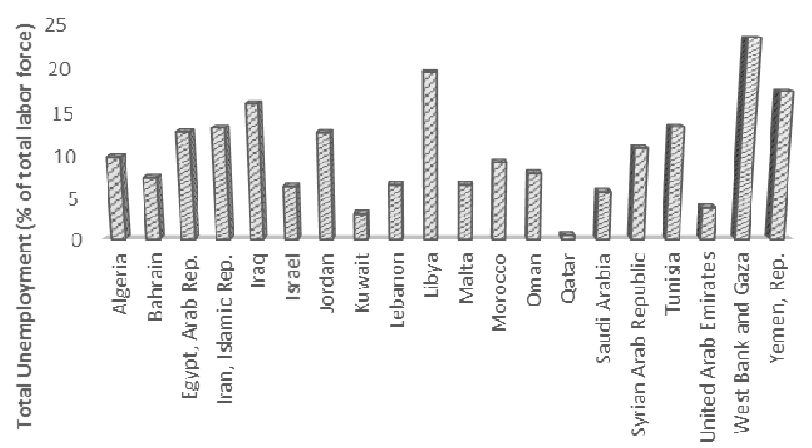

MENA Countries

Figure (2): Total Unemployment in MENA Region in 2013

Source: The World Development Indicators Database

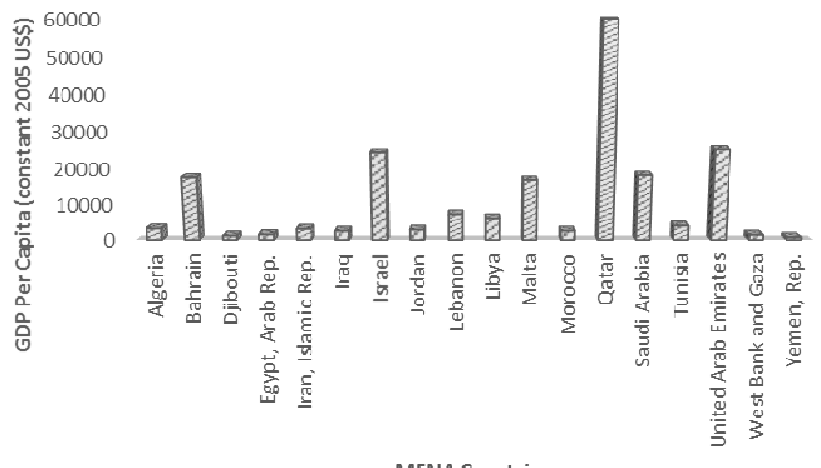

Figure (3): GDP Per Capita in MENA Region in 2013

Source: The World Development Indicators Database 
This variation is also present when comparing the corruption level in MENA Countries. This can be easily deduced from table (1) in which various countries of the MENA region are ranked in accordance to their corruption perception index (CPI). ${ }^{4}$ Nevertheless, there are still some common characteristics with respect to corruption in these countries. For instance, with few exceptions, corruption with all its types is widespread in the MENA Countries. It is deeply embedded in its public sector and ruling regimes. This in turn hinders all the efforts made to prosper and develop. For that, the MENA region is ranked constantly below the world median as suggested by the Transparency International Organization. Not only this, but even when compared to similar income groups, corruption is higher in the MENA countries.

Looking at the pollution emissions level in the MENA region does not lead to a different conclusion. Carbon dioxide emissions level is very high in the MENA region. According to the Carbon Dioxide Information Analysis Center ranking in 2009, Qatar is the highest in the world in CO2 emissions per capita, Kuwait is the third, the United Arab of Emirates is the fifth and Saudi Arabia is the tenth. ${ }^{5}$ This has been commonly attributed to the rise in energy consumption level in the past few years. The rising population, global patterns of consumption or even the increase in the production of fossil fuels are among the possible causes as well (Dargin, 2013). Figure (4) compares between CO2 per capita in MENA countries in 1990 and 2010. In most of the countries, there is a rise in $\mathrm{CO} 2$ emissions per capita with the exception of Bahrain.

In conclusion, it is evident that there are high levels of corruption and pollution emissions in the MENA region. Knowing the economic challenges that the MENA countries have necessitates studying the effects of corruption on pollution emissions level in these countries.

Table (1): CPI 2014 Score of MENA Countries

\begin{tabular}{|c|c|c|}
\hline Country Rank & Country & CPI 2014 Score \\
\hline 25 & United Arab Emirates & 70 \\
\hline 26 & Qatar & 69 \\
\hline 37 & Israel & 60 \\
\hline 43 & Malta & 55 \\
\hline 55 & Bahrain & 49 \\
\hline 55 & Jordan & 49 \\
\hline 55 & Saudi Arabia & 49 \\
\hline 64 & Oman & 45 \\
\hline 67 & Kuwait & 44 \\
\hline 79 & Tunisia & 40 \\
\hline 80 & Morocco & 39 \\
\hline 94 & Egypt & 37 \\
\hline 100 & Algeria & 36 \\
\hline 107 & Djibouti & 34 \\
\hline 136 & Iran & 27 \\
\hline 136 & Lebanon & 27 \\
\hline 159 & Syria & 20 \\
\hline 161 & Yemen & 19 \\
\hline 166 & Libya & 18 \\
\hline 170 & Iraq & 16 \\
\hline
\end{tabular}

Source: Transparency International Organization

4 According to the Transparency International Organization, the CPI ranks countries based on the corruption perception of the public sector. It ranges from 0 (highly corrupt) to 100 (no corruption). For more information, visit http://www.transparency.org

5 Carbon Dioxide Information Analysis Center, Environmental Sciences Division, Oak Ridge National Laboratory, Tennessee, United States http://www.indexmundi.com/facts/indicators/en.atm.co2e.pc/rankings 


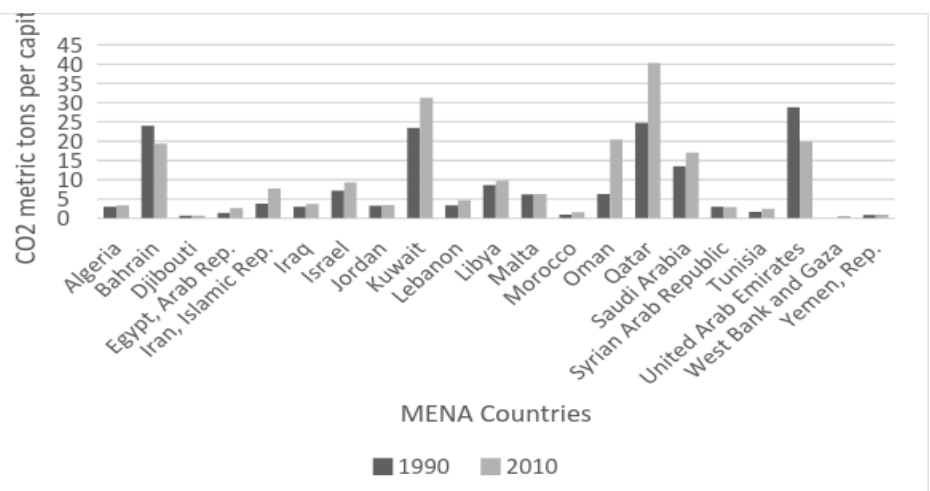

Figure (4): CO2 Per Capita in MENA Region in 1990 \&2010

Source: The World Development Indicators Database

\section{Theoretical Review with Empirical Evidences}

There are several theoretical studies such as those of Fredrikson et al.(2004) and Damania et al. (2003) that indicate that there is an inverse relationship between corruption and the environment. This is apparent in the effect of corruption on stringency of environmental laws. The more spread the corruption is, the weaker the enforcement of and compliance with environmental laws shall be. This results into lax environmental laws which in turn reduce social welfare (Fredriksson and Svensson, 2003). Accordingly, it is expected to have higher levels of pollution emissions in corrupt economies. In line with that, Sundstrem (2013) categorized the effect of corruption on environment into two types. The first type is represented through the effect of corruption on the content of the environmental laws in which lax laws in terms of penalties or standards are more likely to be found in corrupt countries. The second type is represented through the practical application of the environmental laws in which one may have a stringent environmental law in content; however, it is not enforced due to the spread of corruption. In both cases, pollution emissions level and environmental degradation will increase (Sundstrem, 2013).

Another theoretical dimension can be inferred from the Environmental Kuznets Curve (EKC) hypothesis. According to Dasgupta et al. (2002); Cole et al. (1997) and Grossman and Krueger (1995), EKC assumes that there is an inverted U shaped relationship between pollution emissions level and per capita income. Cole (2007) argues that through its explicit effect on per capita income, corruption will implicitly affect pollution emissions level. Thus, corruption has direct and indirect effects on the environment.

Empirical evidences confirm the existence of an inverse relationship between corruption and the environment. For instance, Desai (1998) studied the environment-corruption relationship in 10 developing countries. His results showed that corruption is an influential factor of environmental degradation. Fredriksson and Mani (2002) studied the effect of corruption of policy makers on the environment in a cross section data model of 83 countries. Their results indicated that corruption has a negative effect on stringency of environmental laws. Not only this, but also Damania et al. (2003) studied the relationship between trade openness, corruption and the environment in 48 countries. Among their findings is that corruption decreases pollution tax in general. In addition, they showed that consumer awareness increases the pollution tax. However, this relationship is violated with the existence of corruption. Furthermore, in a cross section study of the European Union (EU), Pellegrini and Gerlagh (2006) showed that there is a statistically 
significant relationship between corruption and the environment when the corruption perception index and environmental regulatory regime index were used. Also, they showed that corruption level contributes to environmental degradation more than per capita income does.

Regarding the EKC hypothesis and corruption, Cole (2007) studied the direct and indirect effects of corruption on pollution emissions level in 94 countries over the period 1987-2000. His results indicated that corruption has a positive direct effect on pollution emissions levels represented by carbon dioxide and sulfur dioxide emissions per capita. In addition, he showed that there is an indirect effect of corruption on these two pollutants emissions levels through the negative effect of corruption on per capita income. In line with that, Welsch (2004) studied the direct and indirect effect of corruption on pollution emissions levels. His results indicated that presence of a positive direct relationship between corruption and pollution emissions levels that prevail over the indirect effects.

The literature is rich in studying the effects of corruption on the economy in the MENA region. ${ }^{6}$ However, empirical studies on the effect of corruption on the environment in the MENA region has become important only recently and still are not comprehensive. When reviewing the literature, few research papers fell within this domain. For instance, Goel et al. (2013) studied the effects of corruption and shadow economy on pollution emissions level in a sample of more than 100 countries over the period 2004-2007. Their results indicated that low levels of recorded emissions are more likely to find in corrupt countries and countries with strong shadow sectors. Nevertheless, higher rates of pollution emissions levels are found in the MENA region. Also, Farzanegan and Markwardt (2012) studied the effect of improving democracy on promoting growth with environmental sustainability. This was conducted in a panel data model and their results showed that the extent of democracy in the institutions has higher effects on the environment domestically than globally. For that, this research work represents a step forward in understanding the relationship between corruption and the environment in general and in filling the gap present in the literature in analysing this relationship in the MENA region in particular.

\section{The Empirical Model}

The empirical model studies the corruption-environment relationship through examining the effect of corruption on per-capita carbon dioxide emissions level founded on the econometric work of Cole (2007). A Panel Data model is used to investigate the effects of corruption, per-capita income, trade openness and manufacturing on per-capita carbon dioxide emissions in the MENA region over the period 1996-2013 for which data is available. ${ }^{7}$

\subsection{The Econometric Approach}

The following fixed effect panel data model with homogenous slopes is considered:

\section{$\log E M_{z}=\alpha \log C O R_{z}+\beta \log X_{\alpha}+\lambda_{t}+\epsilon_{t}$}

For country $\mathrm{i}$ at time t, EM is the per-capita carbon dioxide emissions measured in metric tons per capita; COR is the measure of corruption level; $\mathrm{X}$ is a vector of independent variables that affect emissions level other than corruption; $\lambda$ is the fixed effect dummy variable for individual unobserved effects and $\varepsilon$ is the error term. There are many advantages of using a panel data set such as the increase of the sample size which in turn results in a better estimation and increases the power of the test statistics. For that, it is more preferred to cross section or time series sets.

${ }^{6}$ Refer to Méon and Sekkat (2004), Guetat (2006) and Mina (2011).

7 The list of countries includes: Egypt, Jordan, Lebanon, Malta, Morocco, Oman, Qatar, Saudi Arabia, Tunisia, United Arab of Emirates and West Bank and Gaza. 


\subsection{The Choice of Variables}

There are many measures used to assess corruption level. Among these are the corruption perception index which is used by many researchers such as Tavares (2004) and Bakare (2011). However, it is usually accused of being biased due to its reliance on surveys that are subject to value judgment and perception (Rao and Marquette, 2012). ${ }^{8}$ Also, there is another measure of corruption constructed by the International Country risk guide which is used by some researches such as Cole (2007). However, due to its dependence on expert opinions, it is not used in this study.

This research work uses instead the control of corruption indicator constructed by the WB. ${ }^{9}$ This is because although it still relies on perception, yet it is more comprehensive. It depends on the aggregation of more than 30 indices reflecting the point of view of individuals, enterprises and experts. Also, it is used before by many researchers such as Wei (1997) and Zhou (2007). This indicator ranges from -2.5 (low control of corruption) to +2.5 (high control of corruption). Since, it measures the extent of control of corruption, it is expected to affect pollution emissions negatively.

In addition to the control of corruption, per capita income, manufacturing value added and trade openness are used to test their effects on pollution emissions level. ${ }^{10}$ Per capita income is used to test the effect of income on pollution emissions level. It is expected to have a negative relationship between pollution emissions and per capita income if the country uses environmental friendly techniques of production. However, if this is not the case, then the relationship will be positive. The same logic applies to manufacturing value added in which the share of industry in GDP is measured to assess the effect of manufacturing on pollution emissions level. This is because, manufacturing is always been accused of increasing pollution. Hence, the nature of the relationship is still indistinct. Finally, trade openness measured by the sum of exports and imports to GDP is used. The logical reason behind this is that trade liberalization can affect pollution emissions levels. Again, the nature of the relationship is indefinite, depending on the type of traded goods. It is important to highlight that a trend term was introduced to the estimation, however, it was excluded due to results were not meaningful.

To measure pollution emissions level, carbon dioxide per capita is used. Carbon dioxide is valid measure for pollution emissions. This is because it is the main source of global warming. In addition, it is widely used by many researchers such as Yaung (2001) and Holtz- Eakin and Selden (1995). Also, it is strongly correlated with other pollutants. ${ }^{11}$ All data are obtained from the World Development Indicators and the World Bank Governance Indicators databases.

\subsection{Estimation}

To assess the effect of corruption on pollutions emissions level in the MENA region, a panel data model is used. The sample studied is for 11 countries over the period 1996-2013. Logs were used in the estimation, accordingly a constant term was added to the control of corruption indicator to get rid of the negative sign. ${ }^{12}$ Hausman test between fixed effects and random effects models was used. The result of this test indicated the rejection of the random effect model. Accordingly, fixed effect panel data model was used as indicated in equation 1. Table (2) shows

8 Also, Olken (2006); Donchev and Ujhelyi (2009); Rose and Mishler (2008) and Smith (2008) gave evidence for the invalidity of the corruption perception index.

${ }^{9}$ See http://info.worldbank.org/governance/wgi/index.aspx\#home

${ }^{10}$ See Mihici (2005), Cole (2007) and Hassaballa (2013).

11 Hoffmann et al. (2005) showed that the correlation coefficients of carbon dioxide with nitrous oxide and sulfur dioxide are 0.9529 and 0.9536 respectively.

12 For more information see www.medcalc.org/manual/log transformation.php 
the results of the panel least square estimation of equation 1 in which at time $t$ in country $i, \log$ carbon dioxide emissions measured in metric ton per capita (CO2) is regressed on log of control of corruption (COR), log of per capita income (Y), log of manufacturing value added (MANU) and $\log$ of trade openness (TO). All variables were significant with the exception of corruption and trade openness. For that, a white test was conducted to test for heteroskedasticity. The results of the test indicated its presence. To have consistent estimators, generalized least squares (GLS) weights and White correction were used as a robust check. The results of these estimations are shown in table (3) and table (4) respectively.

Table (2): Empirical Results of Equation 1a

\begin{tabular}{|cc|}
\hline $\begin{array}{c}\text { Dependent Variable } \\
\text { Log CO2 }\end{array}$ & Coefficients \\
\hline Log COR & -0.174504 \\
& $(-1.271878)$ \\
Log Y & 0.501286 \\
& $(5.184558)^{*}$ \\
Log MANU & 0.444918 \\
& $(5.232567)^{*}$ \\
Log TO & 0.127602 \\
& $(1.438475)$ \\
Constant & -1.802438 \\
& \\
Adjusted R Squared & 0.977907 \\
\hline
\end{tabular}

a t- values are in parentheses; ${ }^{*}$ Significance at $1 \%, 5 \%$ and $10 \%$ levels

Table (3): Empirical Results of Equation 1a (GLS)

\begin{tabular}{|cc|}
\hline $\begin{array}{c}\text { Dependent Variable } \\
\text { Log CO2 }\end{array}$ & Coefficients \\
\hline Log COR & $-0.136259)$ \\
& $(-5.8722774)^{*}$ \\
Log Y & 0.506037 \\
& $(30.35279)^{*}$ \\
Log MANU & 0.417421 \\
& $(24.75938)^{*}$ \\
Log TO & 0.127474 \\
& $(8.679567)^{*}$ \\
Constant & -1.808316 \\
& \\
Adjusted R Squared & 0.998933 \\
\hline
\end{tabular}

${ }^{a} \mathrm{t}$ - values are in parentheses; $*$ Significance at $1 \%, 5 \%$ and $10 \%$ levels

Table (4): Empirical Results of Equation 1a (White Correction)

\begin{tabular}{|cc|}
\hline $\begin{array}{c}\text { Dependent Variable } \\
\text { Log CO2 }\end{array}$ & Coefficients \\
\hline Log COR & -0.136259 \\
& $(-10.69865)^{*}$ \\
Log Y & 0.506037 \\
& $(42.11101)^{*}$ \\
Log MANU & 0.417421 \\
& $(24.94261)^{*}$ \\
Log TO & 0.127474 \\
& $(9.152771)^{*}$ \\
Constant & -1.808316 \\
& 0.998933 \\
\hline
\end{tabular}


${ }^{a}$ t- values are in parentheses; $*$ Significance at $1 \%, 5 \%$ and $10 \%$ levels

After applying general least squares weights and White correction, the empirical results of equation 1 indicate the following: All explanatory variables are found significant and with the expected signs. The coefficient of control of corruption is significant and negative as expected. This indicates that pollution emissions decrease with control of corruption in the MENA region. With respect to all other variables' coefficients, they are significant and positive. This indicates that pollution emissions levels increase with economic growth, manufacturing and trade openness. This implies that there is an overdependence on polluting techniques in production in the MENA region.

\section{Conclusion and Policy Implications}

This research work examined the effect of control of corruption, per capita income, manufacturing value added and trade openness on carbon dioxide emissions levels per capita in the MENA region. This was estimated in a fixed effect panel data model in three regressions. After correcting for heteroskedasticity through GLS weights and White correction, all explanatory variables got the expected signs and were significant. Two main results are deduced from these estimations: (i) The presence of a negative relationship between control of corruption and pollution emissions level in the MENA region. (ii) The usage of polluting techniques in production in the MENA region as suggested by the significantly positive coefficients of per capita income, manufacturing value added and trade openness. Accordingly, policy implications that tackle these two results are suggested as follows:

1. Set clear specifications in legal laws with determined penalties to avoid any room for corruption.

2. Strong enforcement of the law through monitoring, inspecting and applying the appropriate regulatory approach.

3. Give incentives to firms in the form of financial, technical and economic assistance such as tax breaks for instance, to abide by the legal standard of pollution emissions level and to have strong compliance.

4. Increase transparency through declaring to the people all the information needed regarding the economic activity, expenditures and income of the public sector. In addition, be more accurate in releasing information about the country's economic conditions to precisely reflect what is and not what ought to be.

5. Use environmental friendly techniques in production in general and in manufacturing in particular. This can be through implementing a national program of credits offered to firms to substitute their old polluting techniques of production with environmental friendly ones.

6. Raise public awareness through the media about the importance of changing their consumption and production patterns to reduce pollution emissions levels and to preserve the environment.

7. Utilize all sources of revenues coming into the country to end up with a possible plan for increasing wages. This is because it is generally believed that low payments of a job can induce corruption.

8. Study successful stories of countries that excelled in its pollution and corruption controls to test their applicability in the MENA region.

9. Teach children at schools about the ethical considerations related to corruption and environmental degradation to have a new generation that condemns corruption and respects its environment.

These are few suggestions of policy implications that can be used to impose more governance and environmental sustainability. Governments and individuals in the MENA region, in particular, should put more emphasis in implementing these recommendations to ensure a cleaner 
environment with less corruption.

\section{Acknowledgment}

The author would like to thank Prof. Alaa Al-Shazly for his valuable support.

\section{References}

Bakare, A. (2011). The crowding-out effects of corruption in Nigeria: an empirical study. Journal of Business Management and Economics, 2, 59-68.

Carbon Dioxide Information Analysis Center, Environmental Sciences Division, Oak Ridge National Laboratory, Tennessee, United States http://www.indexmundi.com/facts/indicators/en.atm.co2e.pc/rankings

Cole, M. A. (2007). Corruption, income and the environment: an empirical analysis. Ecological Economics, 62, 637-647.

Cole, M. A., Rayner, A.J. and Bates, J.M. (1997). The environmental Kuznets curve: an empirical analysis, Environment and Development Economics. 2, 401-416.

Damania, R., Fredriksson, P.G. and List, J. A. (2003). Trade liberalization, corruption, and Environmentl policy formation: theory and evidence. Journal of Environmental Economics and Management, 46, 490512.

Dargin, J. (2013). MENA faces up to carbon challenge. Petroleum Economist,10-13. http://www.academia.edu/3618497/MENA Faces_Up to Carbon_Challenge

Dasgupta, S., Wang, H., and Wheeler, D. (2002). Confronting the environmental Kuznets curve. Journal of Economic Perspectives, 16, 147-168.

Desai, U. (Eds.). (1998). Ecological Policy and Politics in Developing Countries: Growth, Democracy and Environment. Albany: State University of New York Press.

Donchev, D., and Ujhelyi, G. (2009). What do corruption indices measure? Working Paper Series. http://papers.ssrn.com/sol3/papers.cfm?abstract id=1124066

Farzanegan, M. and Markwards, G. (2012). Pollution, economic development and democracy: evidence From the MENA countries. MAGKS Papers on Economics (201227), Philipps-Universität Marburg, Faculty of Business Administration and Economics, Department of Economics.

Fredriksson, P. and Mani, M. (2002). The rule of law and the pattern of environmental protection. IMF Working Papers (WP/02/49). http://www.imf.org/external/pubs/ft/wp/2002/wp0249.pdf

Fredriksson, P. and Svensson, J. (2003). Political instability, corruption and policy formation: the case of environmental policy. Journal of Public Economics, 87, 1383-1405.

Fredriksson, P., Vollebergh,H.R.J. and Dijkgraaf, E. (2004). Corruption and energy efficiency in OECD countries: theory and evidence. Journal of Environmental Economics and Management, 47, 207-231.

Goel, R., Herrala, R. and Mazhar, U. (2013). Institutional quality and environmental pollution: Mena countries Versus rest of the world. Economic Systems,37, 508-521.

Grossman, G. M. and Krueger, A. B. (1995). Economic growth and the environment. Quarterly Journal of Economics, 353-357 (May).

Guetat, I. (2006). The effects of corruption on growth performance of the MENA countries. Journal of Economics and Finance, 30, 208-221.

Hassaballa, H. (2013). Environment and foreign direct investment: policy implications for developing countries. Journal of Emerging Issues in Economics, Finance and Banking, 1, 75-106.

Hoffmann, R., Lee, C., Ramasamy, B. and Yeung, M..(2005). FDI and pollution: a Granger causality Test using panel data. Journal of International Development. 17, 311-317.

Holtz-Eakin, D and Selden T. (1995). Stoking the fires? $\mathrm{Co}_{2}$ emissions and economic growth. Journal of Public Economics, 57, 85-101.

MedCalc Website www.medcalc.org/manual/log transformation.php retrieved in Feb, 2015.

Méon, P.G. and Sekkat, K. Does the quality of institutions limit the MENA's integration in the world economy? The World Economy, 27, 1475-1498.

Mihci, H., Cagatay, S and Koska, O. (2005). The impact of environmental stringency on the foreign direct investment of the OECD countries. Journal of Environmental Assessment Policy and Management 7, 679704.

Mina, W. (2011). Institutional reforms debate and FDI flows to MENA region: does one 'best' fit all? 
WIDER Working Paper (WP/50):UNU-WIDER. http://www.wider.unu.edu/publications/workingpapers/2011/en GB/wp2011-050/

Olken, B. (2006). Corruption perceptions vs. corruption reality. NBER Working Paper Series (working Paper 12428). http://www.nber.org/papers/w12428.pdf

Olken, B. A. and Pande, R. (2012). Corruption in developing countries. Annual Review of Economics, 4, 479505.

Pellegrini, L. and Gerlagh, R. (2006). Corruption, democracy, and environmental policy: an empirical contribution to the debate. Journal of Environment and Development, 15, 332-354.

Rao, S. and Marquette, H. (2012). Corruption indicators in performance assessment frameworks for budget support. Bergen: Chr. Michelsen Institute (U4 Issue).

Rose, R. and Mishler, W. (2008). Seeing is not always believing: measuring corruption perceptions and experiences. Prepared for the Elections, Public Opinion and Parties 2008 Annual Conference, The University of Manchester, The United Kingdom.

Smith, M. (2008). Citizens' corruption perceptions in international comparison: the role of social status And the interplay of individual and country level effects. Paper presented at the American Sociological Annual Meeting, Boston.

Sundstrem, A. (2013). Corruption in the commons: Why bribery hampers enforcement of environmental regulations in South African fisheries. International Journals of the Commons. 7, 454-472.

Tavares, A. (2004). The socio-cultural and political-economic causes of corruption: a cross-country analysis. Working Paper in Economics (wpaper:192004): Universidade de Aveiro. https://ideas.repec.org/p/ave/wpaper/192004.html

The United Nations Convention Against Corruption. (2004). New York: The United Nations. http://www.unodc.org/documents/treaties/UNCAC/Publications/Convention/08-50026 E.pdf

The World Bank. (2014). Middle East and North Africa Overview. http://www.worldbank.org/en/region/mena/overview\#1

The World Development Indicators (http://data.worldbank.org/data-catalog/world-developmentindicators)

The Worldwide Governance Indicators (http://info.worldbank.org/governance/wgi/index.aspx\#home)

Transparency International Organization (http://www.transparency.org)

Wei, Shang-Jin. (1997). Why is corruption so much more taxing than tax:? arbitrariness kills. NBER Working Paper (working paper 6255). www.nber.org/papers/w6255.

Welsch, H. (2004). Corruption, growth and the environment: a cross-country analysis. Environment and Development Economics, 9, 663-693.

Yaung H. (2001). Trade liberalization and pollution: a general equilibrium analysis of carbon dioxide emissions in Taiwan. Economic Modelling, 18,435-454.

Zhou, Y. (2007). An empirical study of the relationship between corruption and FDI: with sample selection error correction.www.etsg.org/ETSG2007/papers/zhou.pdf 
